\title{
A Literary Genre in Value Education in History Courses: Poems
}

\author{
Sezai Öztaş \\ Correspondence: Sezai ÖZTAŞ, Kırklareli University, Faculty of Arts and Science, Department of History, Turkey.
}

Received: March 5, 2018

doi:10.11114/jets.v6i5.3078

\author{
Accepted: March 20, 2018 \\ Online Published: March 25, 2018
}

URL: https://doi.org/10.11114/jets.v6i5.3078

\begin{abstract}
One of the objectives of education in schools is to acquire values. In this sense, history courses are among the important courses in which students can acquire values. Students can acquire values such as justice, peace, honesty, empathy, tolerance, human rights, respect, love, responsibility, charity, patriotism, etc. through history courses. There are many materials in history courses that support value education and that can be used in value education. One of these materials is poetry. It is possible to detect the historical events of the period they were written and the values of society. From this perspective, it is important to use poems in value education in history education. Different learning environments will be granted for students through the use of poetry in value education in history courses. Furthermore, the use of such different materials in the acquisition of values in history lessons will enable further internalization of values. In this study, the fact that value education could be carried out via the use of poetry in history courses was tried to be explained. With this purpose in mind, a theoretical framework for the relation between values and poetry was aimed to be put forward and how poetry could be used in value education in history courses was tried to be explained.
\end{abstract}

Keywords: history, history education, values education, poems and values education

\section{Introduction}

The history of values education dates back to the first studies of character education in America in the 1920s. During the 1930 's the interest in the character education was on the decline and this situation continued until the second half of the 1960's. The studies on values education have been published beginning from the mid-1970s. When these studies on values education are examined, names such as Rokeach, Simon, How, Raths, Harmin, Kirschenbaum, Kohlberg stand out. That the value education went through a recession in the 1980s is clearly seen. While the emphasis placed on social and moral values decreased in the 1990s, individual harmony values shone out. Developments that signal a downfall in the social sense (youngsters' sexual addiction, substance abuse, early pregnancy, suicides, increased divorce rates, etc.) have brought values and moral education back to the agenda. Families, educators and community leaders have begun to emphasize moral and value education in schools in the face of these adverse developments (Demircioğlu \&Tokdemir, 2008). From the 2000s onwards, in parallel with these developments, studies on value education have gained momentum. Within this framework, there has been an increase in the number of books, journals and international symposiums related to values education.

The important task of schools is to teach students values through explicit or implicit programs, to discipline students in line with established rules, to contribute to the moral development of students, and to influence the character and self-perception of students positively. Apart from the cognitive domain, students learn values like respecting people, being tolerant, successful and charitable; social norms like obeying the traffic rules; moreover, they learn to develop positive attitudes towards the teachers and courses, and to adopt proper attitudes towards situations they encounter in schools (Akbaş, 2004). As it can be seen, one of the important tasks of the schools is to provide value education for the students.

Value education occurs in schools at all times. However, this education needs to be acquired with planned learning experiences as a part of formal education. In this context, it is important to answer the following six questions in order to be able to bring value education to the schools (Doğanay, 2010: 257-258):

-Why? Why should we teach kids values?

- What? What are the values that children need to acquire?

-When? When should we start teaching children values?

- Where? Where should we teach children values?

- Who? Who should teach kids values? 
- How? How can we teach children values?

According to Veugelers (2000: 44) teachers have a greater influence on the curriculum in practice and they cannot remain neutral with regard to expressing certain values in their teaching. One of the answers to the question "How can we teach values in history courses?" is to benefit from teaching materials. One of the teaching materials that can be used in value education in history courses is poetry.

\section{Method}

The purpose of this study is to establish a theoretical framework for the relation between values and poetry in history education and to explain how poetry can be used in value education in history courses. For this purpose, answers to the following questions have been sought:

- What is value and value education?

- What is the place of values in history education?

- Why poetry should be integrated into history classes for value education?

- How can poetry be used in value education in history courses?

\section{Value and Value Education}

A great number of researches in relation to the concept of value used in many scientific fields, such as philosophy, economics, mathematics, psychology, sociology, history and so on., have been carried out up to now and several different definitions of value have been proposed in the literature. Rokeach (1973) defines value as "an enduring belief that a specific mode of conduct or end-state of existence is personally or socially preferable to an opposite or converse mode of conduct or end-state of existence". Güngör (1993: 18) defines value as "the belief that something is able or unable to be desired." Halstead \& Taylor (2000: 169) defines values as "principles and fundamental convictions which act as general guides to behavior, the standards by which particular actions are judged to be good or desirable." Schwartz (1992: 1) states that theoricians view values as "criteria people use to select and justify actions and evaluate people (including the self) and events".

The properties must be known in order to better understand what the values are. The properties of the values can be listed as follows:

- Values are beliefs. However, they are not entirely objective, free of emotions. When they come into action, they are interlaced with the emotions.

- Values are related to the individual's goals (such as equality) and their way of behaviour (minding qualification, charity) which are effective in achieving these goals.

- Values outweigh specific actions and situations. For example, the value of obedience applies to all of our relationships with people at home, at work, at school and with people that we do not know.

- Values serve as standards that guide the selection or change of behaviors, people and events.

- Values are sorted according to their prominence. This ordering creates a system that determines the value priorities. Cultures and individuals can be described by the value priorities systems which they put into practice.

- Values are mutable constructs. There may be changes in value priorities in order to meet new needs that arise in time as a result of interaction.

- Values vary according to the cultures they are affiliated with. Yet more they may even show separation within the cultures they belong to. Two different societies may have the same value, but the level of importance that they adhere to this value may be different (Yazıc1, 2006: 504).

Value education puts good human upbringing in the centre. Value education is "all the activities that are carried out to bring up people who exhibit behaviors which are signaled by the expressions of empathy, toleration and developing social awareness" (Ekşi \& Katılmış, 2011). Value education aims to strengthen the transfer of values in education through the curriculum and the moral atmosphere in schools (Veugelers, 2000). The curriculum and the moral atmosphere in the schools thereby contribute to the value development of the students.

Today, when the studies on value education are analyzed, it is seen that an education concept, by name of "enhanced character education" that is inclusive of value and moral development is aimed to be applied. Although personal preferences and individual values appear to be in the foreground in this understanding, this does not necessarily mean that school's task of socializing is left behind. This understanding is inclusive of interrelated areas such as value education, social skills education, moral education, and citizenship education. The change in social and individual life increases the significance of values. In this regard, educators, social psychologists and psychologists are to study on values in the future (Demircioğlu \& Tokdemir, 2008: 73-74).

\section{History Education and Values}

There are three areas of learning: cognitive, psychomotor and affective learning in the education process. Affective 
learning, one of these learning areas, includes values, as well. History courses is one of the important courses addressing the affective learning. History courses is one of the important courses that support students' acquisition of values. A great many researches reveal that history courses play an important role in value education (Arthur et al., 2001; Demircioğlu \& Demircioğlu, 2016; Demircioğlu \& Tokdemir, 2008; Gültekin 2007; Halbert, 2009; Mutluer, 2015; Safran, 2008; Shemilt, 1992; Tokdemir, 2007; Ulusoy, 2005; Ulusoy 2007a; Ulusoy 2007b; White, 1992; Young, 1996).

Expectations with regard to history education have undergone changes from time to time. These expectations were mainly restricted to the preparation of administrative candidates for the art of management until the 16th century, after this period the interpretation of religious texts and the provision of materials for teaching classical languages were added to these expectations. However, with the rise of political nationalism, history has begun to be put in schools' curricula as a scientific discipline and an education program, undertaking the task of building national identity and raising good citizens (Safran, 2008).

Though the expectations related to history education go through changes from time to time, history has been perceived as a fundamental means in the development of democratic values and in the citizenship education of the individual (Arthur et al., 2001; Dilek, 2002; Demircioğlu \& Tokdemir, 2008; Halbert, 2009; Shemilt, 1992). History is thought to nourish the development of national sentiments within the context of citizenship education, respect for human rights, democracy and cultural rights, the development of cultural identity, and so on, with analectic events and phenomena (Dilek, 2002).

Although history education is mainly devoted to the development of mental skills today, it is an important field to support citizenship and value education. The history, which enables us to take lessons from the past, serves as a prominent means of conveying values to people. The events encountered in history courses and the values revealed by these events both teach new values to students and enable them to question current values (Demircioğlu \& Tokdemir, 2008).

Researchers such as Ferro, Blyth, Strom \& Parson have focused on the social objectives of history teaching. As part of social objectives, these researchers regarded history as a means to acquire the spiritual and cultural values that a society needs (Dilek, 2002).

One of the main goals of the history courses that tell the story and legacy of the human being from past to present should be to convey the processes, events and experiences that the society and humanity have experienced starting from the past up to today to the new generation. People's beliefs and values played an important role in the actions and activities of themselves in the past. For this reason, historical events and actions cannot be investigated and taught in a healthy way without considering the values. In other words, the place and role of values in the events, actions and occurrence of activities in history should be taught to students in history courses. Today, in order to bring up healthy individuals, history courses should be constructed in a way to support value education (Demircioğlu \& Demircioğlu, 2016).

\section{Poems in Value Education in History Classes}

In Turkish Dictionary, the word "poem" is defined as "literary expression genre that emerges with rich symbols, rhythmic words, harmonious use of sounds" (TDK, 1988: 1386). Tural (2004) notes that poetry is a kind of information, a world of evaluation, a scream intended to convey a message, the words' coherence that is which the result of the need to share a special information reached through meta language in a harmonious way. Societies reflect historical events and values in poems, as well as their sorrow and joy. Thus, poems reflect the collective values of societies.

It will be appropriate to get children to listen to poetry, to read poetry and to discuss the poetry beginning from early ages. A child who has such a habit has the opportunity to recognize a significant portion of the literary and aesthetic values of national and universal cultures at a very early age; and s/he will have taken a step into a realm that will enrich the scope of one's imagination, to enhance the creative power, to enrich the language wealth (Şirin, 1994). The fact that poems have an impressive and striking feature in terms of language and expression makes it important to use poetry in education. In this sense, poems, a kind of literature, should be used to teach value in history courses.

There are available studies which remark that poems should be used in value education (Conroy, 1999; Dodson, 1993; Markert \& Healy, 1983). It is emphasized in these studies that poems enhance values. According to Stiles (1965) "poetry is truth wrapped in beauty". There are also several important studies which emphasize that poetry should be used in history education (Candan, 2003; Çençen \& Akça Berk, 2014; Harrison \& Holderith, 2003; Kenworthy, 1937; Köksal, 2010; McCall, 2004; Osborne, 1987; Öztaş, 2009; Wilson \& Kahn, 2008).

Perhaps the first educator to approach the use of poetry in education, especially in terms of teaching history, was American Leonard S. Kenworthy. In 1937, Leonard S. Kenworthy published an article about poetry as a useful means in teaching American history. Thus, the voices of those who advocate that poems bearing historical messages to be used in history education in the classrooms should take place in history education have begun to be heard (Ata, 2001). According to Kenworthy (1937), American history in verse has great possibilities for effective use in schools. In addition, Kenworthy has also made suggestions in his article for books that can be read about this matter. One of these recommended books is Wallington's work named "American History by American Poets". This is the oldest dated work in the reading list which Kenworthy recommended in his article to draw attention to the relationship between history and poetry. 
According to Candan (2003), a comprehensive history program is the one that includes other reading materials as well. One of these reading materials is poetry. According to Collins (2008) poetry expresses the soul of historical events and provides the human perspective. Poetry is useful for teachers in the classroom in three ways: accessibility, variety and comprehension. These three aspects reveal the potential of poetry to engage students, meet individual needs within the group, and aid in comprehension (Collins, 2008). Öztaş (2009) indicated that making use of poems in history education as a teaching material can contribute to the cognitive and affective development of students and may be effective in teaching them values. Köksal (2010) stated that it would be beneficial to enrich the texts in the course book with different text types such as poetry in solving the problems such as vapidity, incomprehensibility arising from the course books; and that students' skills to read critically, make comparisons and read inter textually can be improved through the use of poems. Also when Çençen \& Akça Berk (2014) tried to determine the views of history teachers regarding the use of poetry in secondary education history courses, they found that the history teachers' participation rates related to the use of poetry in their courses were high.

Although it is desired to make use of poetry in history education programs and it is possible to find remarkable poems about various topics in terms of value, use of poems in value education is not widespread. The fact that teachers do not have enough knowledge and experience about how poetry can be effectively integrated into history education confronts us as one of the primary reasons for not using poetry.

\section{How Can We Benefit From Poems in Value Education in History Courses?}

One of the means to benefit from in value education in history courses is poetry. Teachers, however, should be aware of the fact that every poem is just not appropriate to be used in history courses. It should not be forgotten that, in the selection of poems, the achievement of value-related outcomes must be prioritized. Otherwise a qualified value education is not even a matter of discussion.

No matter how good the selected poems for acquiring values in history courses are, it may not be possible to achieve the desired objectives and behaviors unless the practice of the poetry activity are well planned. It is therefore important to make good planning when studying on the use of poems in order to acquire targeted values in history courses.

First of all, in order to find poems about the value to be acquired, poems appropriate for the students should be identified by reviewing the poetry anthologies properly. Depending on the plan, it is to be decided whether the whole or part of the poem will be covered. Afterwards, the exercises to be carried out before the use of poetry, during the use of poetry and after the use of poetry should be determined.

The information in the poetry should be supplemented with other sources, which must be available prior to the use of poetry, by the teacher. To acquire the values in the poem, a worksheet consisting of relevant questions should be prepared.

Either the selected poems should be copied and distributed to the students, or it should be made possible for all the students to see the poems with the help of projections, computers, etc. The teacher can either read the selected poems aloud to the class or have students who can read loudly and who is good at reading poems read the poems to the class, or the students can be divided into groups and each group can be asked to read a stanza together.

Students should find the words in poetry whose meaning they do not know in the dictionary and explain them to the students. If the class is divided into groups, each group may be required to analyze and interpret a stanza or a part of the poem. Students may be asked to write texts for impersonation or to personate an afore written text by the teacher. For animation, students may be asked to write texts, or they may be asked to portray a text prepared by the teacher. Resources which are available in advance to support the information in the poetry should be shared and discussed with students in class during the use of poetry.

In order that the poem can be grasped better and the objectives and behaviors can be acquired better, the worksheet consisting of the questions related to the poem should be delivered to the students and the answer sheet should be evaluated by the teacher afterwards.

While poetry is used in history courses, appropriate exercises, relevant to the values in the poem, to foster student creativity and to encourage them for active participation should be done rather than grammar exercises on the poems done in literature courses. Drawing a picture or writing a short story about the values in the poem are possibly effective exercises in revealing the creativity.

Poetry is an appropriate means to assign out-of-class exercises and homework to reinforce the targeted values. For example, students may be divided into groups, each group may be asked to find and bring in different poems on the same topic. Students may be asked to write a poem about the relevant value or character. Thus students can be motived to conduct research on the relevant value. Evaluation activities can be done on these poems and the most beautiful one can be selected, exhibited on the classroom clipboard, published in the school magazine. Books and historical novels, documentaries and historical films can be recommended for students to read and watch about the relevant value or character.

\section{Conclusion and Discussion}

Educators have always wanted to use poetry in education. Teachers made use of poetry in their lessons from time to time. 
Poetry offers rich learning opportunities in value education in history courses. Values such as justice, peace, honesty, empathy, tolerance, human rights, respect, love, responsibility, charity, patriotism, etc. can be acquired in history courses. The use of poetry as a teaching material in value education in history courses will enable students to develop critical thinking skills, abilities for empathy, and achieve their affective goals. The introduction of students with poems that can teach the values will make the courses more colourful and enjoyable. In addition, the use of poetry in value education in history courses can stimulate students' emotions by exciting them and, in this sense, the values can be internalized by the students. It should not be forgotten that the poetry, which is a collective product of collective memory, edifies and refines the human being with meaningful and harmonious ways of writing. For this reason, the role of using poetry in history courses in value education should not come be ignored, and history teachers should include poetry which includes values in their courses.

In the light of this study, following suggestions can be made:

- Poetry should be used in history courses for value education.

- Considering the fact that history teachers generally use the course books as the primary resource, it will be possible for the history teachers to use poetry in the classrooms providing that the history course books include poetry relevant to the values to be acquired.

- In educational faculties of universities, the history teacher candidates should be taught how to teach value. Moreover, present history teachers should be educated with regards to the use of poetry in value education and made aware of the fact that poetry is an effective means in acquiring values.

\section{References}

Akbaş, O. (2004). Evaluation of the degree of reaching of affective goals at the elementary level in Turkish national education system. Unpublished doctoral thesis, Gazi University, Ankara.

Arthur, J., Davies, I., Wrenn, A., Haydn, T., \& Kerr, D. (2001). Citizenship through secondary history. London: Routhledge Falmer. https://doi.org/10.4324/9780203451632

Ata, B. (2001). How will we teach the Gallipoli Campaign?. Türk Yurdu, 21(164), 23-29.

Candan, A. S. (2003). Development of reading comprehension skills in teaching history. Unpublished doctoral thesis, Gazi University, Ankara.

Çençen, N., \& Akça, B. N. (2014). Perspectives of the teachers related to the "use of poem" in secondary education Turkish republic revolution history and kemalism course. Turkish History Education Journal, 3(1), 1-23.

Collins, P. (2008). Using poetry throughout the curriculum. Kappa Delta Pi Record, 44(2), 81-84. https://doi.org/10.1080/00228958.2008.10516500

Conroy, J. (1999). Poetry and human growth. Journal of Moral Education, 28(4), 491-510. https://doi.org/10.1080/030572499103034

Demircioğlu, İ. H., \& Demircioğlu, E. (2016). History education and values. In R. Turan ve K. Ulusoy (Ed.), Education of values in different aspects (pp. 269-285). Ankara: Pegem Akademi.

Demircioğlu, İ. H., \& Tokdemir, M. A. (2008). The role of history education in the process of constructing values: Aims, functions and content. Journal of Values Education, 6(5), 69-88.

Dilek, D. (2002). Learning and development thought in history cources. Ankara: PegemA Yayınc1lik.

Dodson, M. (1993). Teaching values through teaching literature. Bloomington: Education Information Press.

Doğanay, A. (2006). Values education. In C. Öztürk (Ed.), Life sciences and social studies education (pp. 255-286). Ankara: PegemA Yayıncilık.

Ekşi, H., \& Katılmış, A. (2011). Handbook of character education. Ankara: Nobel Yayın Dağıtım.

Gültekin, F. (2007). Tarih I Dersinde Işse Koşulabilecek Değer Öğretiminin Yeni Yaklaşımlarının Öğrencilerin "Hoşgörü" Değeri Anlaylşlarının Gelişimine Etkisi. Unpublished master's thesis, Gazi University, Ankara.

Güngör, E. (1993). Values Psychology. Amsterdam: Stichting Nederlands-Turks Academisch Genootschap.

Halbert, K. (2009). History teaching and the values agenda. Unpublished doctoral thesis, James Cook University, Australia.

Halstead, J. M., \& Taylor, M. J. (2000). Learning and teaching about values: A review of recent research. Cambridge Journal of Education, 30(2), 169-202. https://doi.org/10.1080/713657146

Harrison, D. L., \& Holderith, K. (2003). Using the power of poetry to teach language arts, social studies, math and more. New York: Scholastic.

Kenworth, L. S. (1937). American history in verse. The Clearing House. 12(3), 169-171. 
https://doi.org/10.1080/00098655.1937.11474642

Köksal, H. (2010). Use of epic poems in history teaching. In M. Safran (Ed.), How is history taught? (pp. 252-257). İstanbul: Yeni İnsan Yayınevi.

Markert, L. F., \& Healy, C. C. (1983). The effects of poetry and lyrics on work values. Journal of Career Education, 10(2), 104-110. https://doi.org/10.1177/089484538301000204

McCall, A. L. (2004). Using poetry in social studies classes to teach about cultural diversity and social justice. Social Studies, 95(4), 172-176. https://doi.org/10.3200/TSSS.95.4.172-176

Mutluer, C. (2015). Tarih Derslerinin Tolerans Eğitimindeki Yeri: Öğretmen Görüşleri. Unpublished doctoral thesis, Atatürk University, Erzurum.

Osborne, K. (1987). Poetry and the teaching of Canadian history: The poems of F. R. Scott. History and Social Science Teacher, 22(3).

Öztaş, S. (2009). The place and importance of poetry in the teaching of history. The 5th International Balkan Education and Science Congress "Education in Balkans Today", Trakya University, October, 1-3, 2009, Edirne, Turkey, 2, 294-298.

Rokeach, M. (1973). The nature of human values. New York: The Free Press.

Safran, M. (2008). History education and learning in Turkey. In M. Safran \& D. Dilek (Ed.). History education, identity and citizenship in the 21st century (pp.13-20). İstanbul: Yeni İnsan Yayınevi.

Schwartz, S. H. (1992). Universals in the content and structure of values: Theoretical advances and empirical tests in 20 countries. Advances In Experimental Social Psychology, 25, 1-65. https://doi.org/10.1016/S0065-2601(08)60281-6

Shemilt, D. (1992). Preface.In P. Lee, J. Slater, P.Walsh \& J. White (Eds.). The aims of school history: The national curriculum and beyond. London: Tufnell Press.

Şirin, M. R. (1994). Child literature in 99 questions. İstanbul: Children's Foundation Publications.

Stiles, L. J. (1965). What shall we do about poetry in the schools? The Elementary School Journal, 65(4), 175-178. Retrieved 16.02.2018 from http://www.jstor.org/stable/999139.

Tokdemir, M. A. (2007). Tarih Öğretmenlerinin Değerler ve Değer Eğitimi Hakkindaki Görüşleri. Unpublished master's thesis, Karadeniz Technical University, Trabzon.

Tural, S. (2004). Speaking about national conscious and the poem. Journal of Atatürk Research Center, 20(60), 821-832.

Türk Dil Kurumu. (1988). Turkish dictionary. Ankara: Türk Dil Kurumu Yayınları.

Ulusoy, K. (2005). Transference of moral values in history lesson "a sample of reading passage". Milli Eğitim, 168, 126-133.

Ulusoy, K. (2007a). Lise Tarih Programlarında Yer Alan Geleneksel ve Demokratik Değerlere Yönelik Öğrenci Tutumlarının ve Görüşlerinin Çeşitli Değişkenler Açısından Değerlendirilmesi. Unpublished doctoral thesis, Gazi University, Ankara.

Ulusoy, K. (2007b). The views of social studies teachers on history and moral education (The case of Sakarya) Journal of Values Education, 5(13), 155-177.

Veugelers, W. (2000). Different ways of teaching values. Educational Review, 52(1), 37-46, https://doi.org/10.1080/00131910097397

White, J. (1992). The purpose of school history: Has the national curriculum got it right?. In P. Lee, J. Slater, P. Walsh \& J. White (Ed.). The aims of school history: The national curriculum and beyond. London: Tufnell Press.

Wilson, C., \& Kahn, B. B. (2008). Using poetry to teach the holocaust: Rationale and strategies for the middle level learner, North Carolina Middle School Association Journal, 23(1). Retrieved 04.12.2009 from http://www.ncmsa.net/journal/PDF/Feb08/Using-poetry.pdf.

Yazıc1, K. (2006). General view to the values education. Türklük Bilimi Araştırmaları, 19, 499-522.

Young, C. (1996). Civics and citizenship and the teaching of history. Unicorn, 22(1), 64-71.

\section{Copyrights}

Copyright for this article is retained by the author(s), with first publication rights granted to the journal.

This is an open-access article distributed under the terms and conditions of the Creative Commons Attribution license which permits unrestricted use, distribution, and reproduction in any medium, provided the original work is properly cited. 